\title{
Quality Evaluation of "Ricotta" Cheese Produced at Laboratory Level
}

\author{
Abdel Moneim E. Sulie man ${ }^{1, *}$, Ais ha S. Eljack ${ }^{2}$, Zakaria A. Salih ${ }^{2}$ \\ ${ }^{1}$ Department of Biology, faculty of Science, Univ ersity of Hail, Kingdom of Saudi Arabai \\ ${ }^{2}$ Department of Food Science and Technology, Faculty of Engineering and Technology, University of Gezira, Wad-Medani, Sudan
}

\begin{abstract}
Ricotta cheese is made fro mheat-acid precipitation of protein fro $m$ whey or whey-milk blend. The study aimed to evaluate the quality characteristics of ricotta cheese produced at laboratory level. The chemical composition of ricotta cheese was as follows: mo isture: $72.89 \%$, protein: $72.89 \%$, protein: $0.14 \%$, fat: $0.6 \%$, ash: $5.37 \%$, pH: 5.28 , acid ity: $1.38 \%$, total solid: $18.41 \%$, Ca: $225 \mathrm{mg} / 100 \mathrm{~g}, \mathrm{~K}: 120 \mathrm{mg} / 100 \mathrm{~g}$ and $\mathrm{Na}: 106 \mathrm{mg} / 100 \mathrm{~g}$. On the other hand, the total viable count was $1.0 \times 10^{4} \mathrm{c}$.f.u/g and yeast and mould count was $2.0 \times 10^{2} \mathrm{c}$.f.u/g. However, all harmful microorganisms were not detected in cheese samples. The sensory evaluation showed that ricotta cheese was generally acceptable. The study recommends encouraging the local dairy industry to introduce ricotta cheese so as to meet the local need and to use whey in the other dairy products.
\end{abstract}

Keywords Chemical Composition, Yeasts And Moulds, Total Viable Count, Sensory Evaluation

\section{Introduction}

Cheese is the name given to a group of fermented milk products produced throughout the world in great variety of flavors, textures and form. Fox et al,[1] suggested that there are more than 1000 varieties of cheese world wide. Walter and Hargrove[2] described about 400 varieties and list the names of a further 400 , while Burkhalfer[3] classifies 510 varieties. Cheese making developed recently with the gradual acquiring of knowledge about the chemistry and microbio logy of milk and cheese which makes it possible to gain more control over the cheese making process. Few new varieties have evolved as a result of increased knowledge, but existing varieties have become better defined and their quality has become more consistent.

The ricotta cheese is a high moisture soft cheese[4]. This cheese can be produced from whey or milk or mixture of both[5]. Ricotta cheese is very mild and it is used in many Italian dishes. Several methods have been developed for utilization of whey; one of these methods is the manufacture of ricotta cheese. Ricotta cheese, which means "re cooked", is produced by boiling acidified cheese whey[6];[7]. All whey protein cheese mixture are ho mogenized and heated at $93^{\circ} \mathrm{C} / 15-30 \mathrm{~min}$. The curd is left in the whey for $10 \mathrm{~min}$. and then scooped in plastic frame lined over a drainage table and allows to achieve complete drainage in $24 \mathrm{hr}$. The curd is

* Corresponding author:

moneim_ug@yahoo.com (Abdel Moneim E. Sulieman)

Published online at http://journal.sapub.org/food

Copyright (C) 2012 Scientific \& Academic Publishing. All Rights Reserved placed in plastic container and stored at $4^{\circ} \mathrm{C}$.

Ricotta cheese is not known or consumed largely in Sudan, and few data is available in this type of cheese, therefore the objectives of the present study were: to evaluate the chemical and mic robiological characteristics of whey, to produce of ricotta cheese at laboratory level using whey and to evaluate the microbiological, chemical and sensory quality characteristics of the manufactured ricotta cheese.

\section{Materials and Methods}

\subsection{Pre paration of Whey Samples}

The whey samples were collected from local market in Wad Medani, central Sudan during April-May 2011. Whey samples were placed in plastic containers and transported to the Department of Food Science and Technology laboratory, Faculty of Engineering and Technology, University of Gazira at cool temperature (at $6^{\circ} \mathrm{C}$ ).

\subsection{Che mical Analyses of Whey}

The $\mathrm{pH}$ of whey was measured using digital $\mathrm{pH}$ meter (PN9410.GL. Britain). The $\mathrm{pH}$ meter was calibrated with buffers of $\mathrm{pH} 4$ and 7. The $\mathrm{pH}$ values were recorded according to AOAC[8].

The titrimetric determination of acidity of whey was accomplished according to the AOAC[9] method. $10 \mathrm{ml}$ sample were taken, and then diluted in $100 \mathrm{ml}$ distilled water, then $10 \mathrm{ml}$ were pipetted into two $100 \mathrm{ml}$ conical flask. The pipettes were washed with distilled water, and six drops of phenolphthalein indicator then added. The samples were 
then titrated with $0.1 \mathrm{~N}$. NaOH until a stable pink color was formed. The titrable acidity was expressed as \% lactic acid from the following formula:

Whey and cheese titrable acid ity

$$
\%=\frac{\mathrm{ml} \text { of } \mathrm{NaOH} \times 0.1 \times 90 \times 100}{\text { Weight of the sample } \times 100}
$$

Where 90 is the amount of lactic acid reacted with $1.0 \mathrm{ml}$ of o. $1 \mathrm{~N} \mathrm{NaOH}$.

The moisture, ash and protein contents of whey samples were determined according to AOAC[8], while fat content of was determined according to the AOAA[9] using Gerber tube. The solid non fat content in whey was determined by using the following formula:

$$
\text { Total solid } \% \text { - fat } \%
$$

\subsection{Microbi ological Analyses}

Ten $\mathrm{ml}$ of whey were ho mogenized with $90 \mathrm{ml}$ of distilled water by shaking for several minutes, fro $m$ this suspension; 1 $\mathrm{ml}$ was taken from the dilution and transferred to another tube to make serial dilution up to $10^{6}$.

Total viable count per $\mathrm{ml}$ was determined by pour plat ing of suitable dilution on melted nutrient agar, and incubated aerobically after solidification at $37^{\circ} \mathrm{C}$ for 72 hour[10].

Yeast and Moulds were enumerated according to Harrigan and MacCance[11] using potato dextrose agar (PDA). The plates were incubated at $25^{\circ} \mathrm{C}$ for $3-5$ days, plates containing between 30 and 300 colonies were count as colony forming units $(\mathrm{cfu} / \mathrm{ml})$.

Coliform bacterial count was determined according to Harrigan and MacCance[11] using MacConkey broth. The tubes were incubated at $37^{\circ} \mathrm{C}$ for 48 hours. Positive tubes gave gas in Durham tubes. Then the positive tubes were sub cultured into EC broth medium and then incubated at $44^{\circ} \mathrm{C}$ for 24 hours, to determine coliform bacteria, the tubes showing gas production were considered positive.

Plates showing positive coliform were subjected to the confirmed test for E. coli using Brilliant green bile broth in test tubes with Durham tube. The test tubes were then incubated at $45^{\circ} \mathrm{C}$ for 48 hours. Each confirmed positive tube was sub-cultured into E.C broth media and then incubated at $45^{\circ} \mathrm{C}$ for 24 hours. Tubes showing any a mount of gas production were considered to be positive[12].

For salmonella detection, $100 \mathrm{ml}$ of samples were incubated at $37^{\circ} \mathrm{C}$ for 24 hours. Then $10 \mathrm{ml}$ were drawn aseptically and added to $100 \mathrm{ml}$ selen ite broth. The broth was incubated at $37^{\circ} \mathrm{C}$ for 24 hours. Then with a loopful streaking was done on dried Bis muth sulphite agar plates. The plates were then incubated at $37^{\circ} \mathrm{C}$ for 72 hours. Black metallic sheen discrete colonies indicated the presence of salmonella. A confirmatory test was carried out by taking a discrete black.

\subsection{Preparation of Ricotta Cheese at Labor atory Level}

Ricotta cheese was made fro $m$ heated acid precipitation of protein from whey. During heating by using a heater (at $79^{\circ} \mathrm{C}$ ), 7 liters of whey protein were coagulated. The rate of coagulation increases as temperature was ra ised to $93^{\circ} \mathrm{C}$ and thick layer of curd was formed on the surface of the whey. When coagulation was completed and the curd was firm (after $10-20 \mathrm{~min}$. at $93^{\circ} \mathrm{C}$ ), the curd was removed from the heater ordinary plastic mesh.10 $\mathrm{ml}$ of lemon juice were immediately added to the resulting curd. After 10 minutes, the mixture was placed in cheesecloth for 2-3 hours. The obtained ricotta cheese was then kept in small plastic container.

\subsection{Cheese Yield}

The resulting cheese was weighed immediately using a weighing balance. The yield of cheese was calculated as follows:

$$
\text { Yield }=\frac{\text { Weight of cheese } \times 100}{\text { Weight of whey }}
$$

\subsection{Ass ess ment of Ric otta Cheese}

The quality of laboratory made ricotta cheese was determined using chemical, microbiological and sensory methods.

The $\mathrm{pH}$, acidity, total solid, solids non fat, moisture, protein, fat and ash were determined as described for the whey.

The microbio logical analyses total viable count, yeast and mould count, coliform count E. coli and salmonella were determined as described for the whey.

\subsection{Sensory Evaluation of Laboratory Made Ricotta Cheese}

The ricotta cheese was subjected to sensory evaluation using 10 panelists. The panelists were asked to rate or to judge samples to be tasted under 9 scales, about the appearance, texture, colour, flavour and the overall acceptability. Each panelist was provided with water for rinsing. The samples were given codes before being tested.

\subsection{Statistical Analyses}

All scores of sensory evaluation were analyzed by the analysis of variance according to SAS[13]. To determine whether there were significant differences between means for each variable; least significant difference (LSD) test was used.

\section{Results and Discussion}

\subsection{Chemical Compositions of Whey Sample and pH}

Table (1) shows the chemical composition of whey samples. The mo isture content was $92.20 \pm 0.23 \%$. This value was slightly lower than that found by Kosikowski (1979), which was $93.7 \%$. The protein content was $0.7 \pm 0.14 \%$, which was lower than that reported by Abozaid[14] who determined a value of $0.9 \%$. The fat content was $0.7 \pm 0.1 \%$, which was higher than that reported by Kosikowski[15], which was $0.3 \%$. The ash content of whey is $5.37 \pm 0.19 \%$. 
This value was higher than that found by Kosikowski[15], which was $0.52 \%$. pH value of whey was $5.1 \pm 0.30 \%$. This value was higher than that reported by DTU National Food institute[16], which was 5.00.The titratable acidity (expressed as \% lactic acid) of whey was $2.35 \pm 0.3 \%$. This value was higher than that of http: //www. Dairy forall.com[17], which was $0.4 \%$. The total solid content was $17.9+0.06 \%$. This value was higher than that reported by http: //www. Dairy forall.com[17], which was $10.5 \%$.

Table 1. Chemical composition of whey sample and $\mathrm{pH}$

\begin{tabular}{cc}
\hline Parameter & Value \\
\hline Moisture & $92.20 \pm 0.23$ \\
Protein \% & $0.7 \pm 0.14$ \\
Fat \% & $0.7 \pm 0.1$ \\
Ash \% & $5.37 \pm 0.19$ \\
pH \% & $5.1 \pm 0.30$ \\
Acidity \% & $2.35 \pm 0.30$ \\
Total solid \% & $17.9 \pm 0.06$ \\
\hline
\end{tabular}

\subsection{Microbiological Analysis of Whey Samples}

Table (2) shows results of the mic robiological analys is of whey samples. The total viable count was $9 \times 10^{4} \mathrm{cfu} / \mathrm{ml}$, this result was higher than that reported by http://www. wolframalph .com/entities[18] which was $4 \times 10^{4}$. The yeast and mould count of whey samples was $6 \times 10^{4}$ $\mathrm{cfu} / \mathrm{ml}$, this result was higher than that reported by http://www.wolframalph .com/entities[18] which was $3 \times 10^{4}$. However, Coliform, E.coli and salmonella were not detected in whey samples indicated the proper sanitary conditions in which the cheese was made.

Table 2. Microbiological analysis of whey samples

\begin{tabular}{cc}
\hline Parameter & Value $(\mathrm{cfu} / \mathrm{ml})$ \\
\hline Total viable count & $9 \times 10^{4}$ \\
Yeast and mould & $6 \times 10^{2}$ \\
E.coli & 0.0 \\
Salmonella & 0.0 \\
\hline
\end{tabular}

\subsection{Chemical Composition of Laboratory-Made Ricotta Cheese}

The chemical composition of laboratory-made ricotta cheese was presented in Table (3). The moisture content cheese was $72.89 \pm 2.6 \%$ which was lower than that of whey $(92.20 \pm 0.23 \%)$. This reduction could be attributed to the effect of high heat treatment which evaporated part of water. However, the result obtained in the present study was lower than that reported by http:www.Dairy forall.com[17], which was $93 \%$ for ricotta cheese.

The protein content of laboratory-made ricotta cheese was $0.6 \pm 0.1 \%$, while it was $0.7 \% \pm 0.14 \%$ in whey. The result was lower than that reported by DTU National Food institute[15], which was $0.8 \%$ for ricotta cheese. The fat content of laboratory-made ricotta cheese was $0.6 \pm 0.1 \%$, while it was $0.7 \pm 0.1 \%$ in whey. The difference did not exceed 0.1 . The result was lower than that reported by DTU National Food institute[16], which was $0.8 \%$ for ricotta cheese.

The ash content of laboratory-made ricotta cheese was $5.37 \pm 0.19 \%$, while it was $6.9 \pm 1.4 \%$ in whey.

$\mathrm{pH}$ value of laboratory-made ricotta cheese was $5.28 \pm 0.23 \%$, while it was $5.1 \pm 0.3 \%$ in whey, and this difference could be attributed to the effect of heat treatment which eliminated the microbial load. The result was similar to that reported by DTU National Food institute[16], who found value of $5.00 \%$ for ricotta cheese.

The titratable acidity was $1.38 \pm 0.6 \%$, while it was $2.35 \pm 0.06 \%$ in whey. The variation in acidity of whey and ricotta cheese may be attributed to storage of whey at room temperature for 12-24 hours before production of ricotta cheese. The result was lower than that reported by DTU National Food institute ([16], who found value of $1.03 \%$ for ricotta cheese. The total solid of laboratory-made ricotta cheese was $18.41 \pm 1.5 \%$, while it was $17.9+0.06 \%$ in whey. The difference did not exceed 0.51 . The result was lower than that reported by DTU National Food institute[16], who found value of $17.5 \%$ for ricotta cheese.

Table 3. Chemical composition of ricotta cheese and $\mathrm{pH}$

\begin{tabular}{cc}
\hline Parameter & Ricotta cheese \\
\hline Moisture\% & $72.89 \pm 2.6$ \\
Protein\% & $0.6 \pm 0.1$ \\
Fat $\%$ & $0.7 \pm 0.1$ \\
Ash\% & $5.37 \pm 1.9$ \\
pH\% & $5.3 \pm 0.23$ \\
Acidity $\%$ & $1.38 \pm 0.06$ \\
Total solid $\%$ & $18.4 \pm 1.5$ \\
yield $\%$ & $7 \mathrm{k}$ \\
\hline
\end{tabular}

\subsection{Microbiol ogical Char acteristics of Labor atory-Made Ricotta Cheese}

Microbiological analyses of laboratory-made ricotta cheese, as shown in Table (4) revealed presence of $1 \times 10^{4}$ $\mathrm{cfu} / \mathrm{ml}$ of total viable count. This result was lower than that found by Rossetti et al., [19], which was $2.8 \times 10^{6} \mathrm{cfu} / \mathrm{ml}$. The lower levels of total bacterial count in laboratory-made ricotta cheese could be attributed to the effect of heat treatment which suppress the growth of mic roorganisms, and also could be attributed to the proper hygienic conditions of cheese production.

The yeasts and moulds count of laboratory-made ricotta cheese was $2 \times 10^{2} \mathrm{cfu} / \mathrm{ml}$. This result was lower than that found by Rossetti[19], which was $8.0 \times 10^{3} \mathrm{cfu} / \mathrm{ml}$. The lower levels of yeasts and moulds count of laboratory-made ricotta cheese were probably due to the effect of higher heat.

Coliform, E. coli and salmonella were not found in laboratory-made ricotta cheese.

The absence of Coliform, E. coli and salmonella in laboratory-made ricotta cheese, were probably due to the 
effect of heat treatment of whey used for the production of ricotta cheese which suppressed the growth of those microorganis ms (pathogenic bacteria).

Table 4. Microbiological analysis of laboratory-mad ricotta cheese

\begin{tabular}{cc}
\hline Parameter & Value $(\mathrm{cfu} / \mathrm{g})$ \\
\hline Total viable count & $1 \times 10^{4}$ \\
Yeast and mould & $2 \times 10^{2}$ \\
Coliform & $\mathrm{Nil}$ \\
E.coli & $\mathrm{Nil}$ \\
Salmonella & $\mathrm{Nil}$ \\
\hline
\end{tabular}

\subsection{Sensory Evaluation}

Table (5) summarizes the mean scores for sensory attributes of the ricotta cheese, Gibna Bayda and lavachequirit. The result indicated slight differences of the various sensory parameters of cheese samples. There were significant differences $p<(0.05)$ of ricotta cheese color and 111lavor when compared with those of Gibna Bayda and lavachequirit. The low scores of 111lavor may be attributed to the distraction of certain LAB responsible for generation 111lavor compound as a result of heat treatment.

Generally, the panelist highly accepted ricotta cheese when compared to Gibna Bayda and lavachequirit. However, there were no significant differences in appearance, texture and overall of the various cheese types.

Table 5. The mean scores for sensory attribut es of the ricotta cheese

\begin{tabular}{cccccc}
\hline \multirow{2}{*}{ Sample } & \multicolumn{5}{c}{ Quality attribute* } \\
\cline { 2 - 6 } & App. & Texture & Color & Flavour & Overall \\
\hline 512 & $7.5 \mathrm{a}$ & $7.3 \mathrm{a}$ & $6.9 \mathrm{~b}$ & $7.0 \mathrm{~b}$ & $7.5 \mathrm{a}$ \\
323 & $8.0 \mathrm{a}$ & $8.1 \mathrm{a}$ & $8.5 \mathrm{a}$ & $8.3 \mathrm{a}$ & $8.2 \mathrm{a}$ \\
415 & $8.4 \mathrm{a}$ & $8.1 \mathrm{a}$ & $8.3 \mathrm{a}$ & $8.6 \mathrm{a}$ & $8.3 \mathrm{a}$ \\
$\mathrm{SC} \pm$ & 0.3036 & 0.3097 & 0.4014 & 0.2617 & 0.5899 \\
$\mathrm{CV} \%$ & 12.05 & 12.5 & 16.07 & 10.39 & 12.77 \\
\hline
\end{tabular}

$512=$ Ricotta cheese

$323=$ Gibna Bayda

415 =lavachequirit

*Means in the same raw bear in the same letter not significant difference

\section{Conclusions}

In the present study the ricotta cheese was prepared at laboratory level using whey which was collected as a byproduct of Gibna Bayda industry. The manufactured ricotta cheese was analyzed chemically, microbiologically and subjected to sensory analysis. Chemical analysis of the manufactured ricotta cheese showed that its main component were $72.89 \%$ mo isture, $0.6 \%$ protein, $0.7 \%$ fat, and $6.9 \%$ ash. Microbial analysis showed that ricotta cheese is free from pathogenic bacteria. The sensory analysis indicated that the ricotta cheese made from whey was highly acceptable by panelist.

From the results of this study it is highly recommended to introduce whey to other food industries, and to encourage the local industry to increase the production of Ricotta cheese so as to meet the local need.

\section{ACKNOWLEDGEMENTS}

The authors express their sincere thanks to all staff members of the Department of Food Science and Technology, Gezira University for their assistance.

\section{REFERENCES}

[1] Fox, P.F, Timothy, M.G, and Mcsweeney, P.L.H, 2000. Fundamentals of cheese science an aspen publication. Aspen Publishers, Inc Gaithersburg, Maryland

[2] Walter, H.E. and Hargrove, R.C, 1972. Cheese of the world. New York: Dover.

[3] Burkhalter, G. 1981. Catalogae of cheese (Bulletin 141). Russels: International Dairy Federation.

[4] Modler, H.W. and Emmons, D. B. 2001. The Use of Continuous Ricotta Cheese Processing to reduce ingredient cost in further processed cheese products. International Dairy Journal 11:517-523.

[5] Pizzillo, m, Claps; Cifunj, G.F.; Fedel, V. and Rubion, R. 2005. Effect of Goat Breed on the Sensory, Chemical and Nutritional Characteristics of Ricotta Cheese Live Stock Production Science 94:33-40.

[6] Maubois, P.L. H., Ottogalli, G, and Fax, P. F, 2004. Diversity of Cheese Varieties: an overview, in Cheese; Chemistry, Physics and Microbiology Vloume 2Major Cheese Group, $3^{\text {rd }}$ edn, P. F. Fox, P. L. H. McSweeney, T. M. Cogan and T. P. Guinee (eds), Elsevier Academic Press, Amsterdam, pp. 1-22.

[7] Mahran, G.A.; Hammad, Y.A., Nawal S. Ahmed; Saged, A.F and Abd El-Aziz, M. 1999. Manufacture of Ricotta Cheese from whey fortifier with skim milk powder using different acidulant .Egyptian J. Dairy Sci., 27:191.

[8] AOAC. (1991). Association of Official Analy tical Chemists. Official Methods of Analysis (14th Ed.).Washington, DC.

[9] AOAC. (2000). Association Of Official Analy tical Chemists, Official Methods of Analy sis (17th Ed.). Arlington, VA. USA

[10] Dirar. H.A., 1976. Optimum temperature for the plate count of milk. Sudan J. Fd. Sci. Technology 8:55-60.

[11] Harrigan W.F. and MacCance, M, E, (1976). "Laboratory methods in food and dairy microbiology". Academic Press. London, New York and San Francisco

[12] Kreger, M. and Kurman-Van-Rij, N. J. W. (Ed).1984. The yeasts a taxonomic study $3^{\text {rd }}$ efn. Elsevier, Amsterdam.

[13] SAS, (1982). SAS User's Guide: Statistics. Statistics Analysis System. SAS Institute. Cary, North Carolina, U.S.A.

[14] Abozaid, N. A. 2007. Dairy Industry Waste and soya Bean Milk. PHD thesis, University of Elmotawafia, Faculty of Agriculture.

[15] Kosikowski, F.V. 1982. Cheese and Fermented Milk Food $3^{\text {rd }}$ 
edition F.V. Kosikowski and Associates. New York.

[16] DTU National Food Institute (2009). Cheese whey. Department of Nutrition, Technical University of Denmark.

[17] http://www.dairy forall.com/whey.php,2011.
[18] http://www.wolframalpha.com/entities 2011

[19] Rossetti, L.; Fornasari, M. E.; Gatti, M.; Lazzi, C.; Neviani,E.; and Giraffa, G. (2008). Grana padano cheese whey starter: microbial composition and strain distribution. Int. J. Food Microbial., 127(1-2):169-171. 